\title{
A controlled trial with vasopressin analogue (DGAW) on cognitive recovery immediately after head trauma
}

Citation for published version (APA):

Bohnen, N. J., Twijnstra, A., \& Jolles, J. (1993). A controlled trial with vasopressin analogue (DGAW) on cognitive recovery immediately after head trauma. Neurology, 43(1), 103-106.

https://doi.org/10.1212/WNL.43.1_Part_1.103

Document status and date:

Published: 01/01/1993

DOI:

10.1212/WNL.43.1_Part_1.103

Document Version:

Publisher's PDF, also known as Version of record

\section{Please check the document version of this publication:}

- A submitted manuscript is the version of the article upon submission and before peer-review. There can be important differences between the submitted version and the official published version of record.

People interested in the research are advised to contact the author for the final version of the publication, or visit the DOI to the publisher's website.

- The final author version and the galley proof are versions of the publication after peer review.

- The final published version features the final layout of the paper including the volume, issue and page numbers.

Link to publication

\footnotetext{
General rights rights.

- You may freely distribute the URL identifying the publication in the public portal. please follow below link for the End User Agreement:

www.umlib.nl/taverne-license

Take down policy

If you believe that this document breaches copyright please contact us at:

repository@maastrichtuniversity.nl

providing details and we will investigate your claim.
}

Copyright and moral rights for the publications made accessible in the public portal are retained by the authors and/or other copyright owners and it is a condition of accessing publications that users recognise and abide by the legal requirements associated with these

- Users may download and print one copy of any publication from the public portal for the purpose of private study or research.

- You may not further distribute the material or use it for any profit-making activity or commercial gain

If the publication is distributed under the terms of Article $25 \mathrm{fa}$ of the Dutch Copyright Act, indicated by the "Taverne" license above, 
The effects of lateralized frontal lesions on mood regulation. Brain 1986;109:1127-1148.

32. Salazar AM, Grafman J, Schlesselman S, et al. Penetrating war injuries of the basal forebrain: neurology and cognition. Neurology 1986;36:459-465.

33. Salazar AM, Grafman JH, Vance SC, Weingartner H, Dillon JD, Ludlow C. Consciousness and amnesia after penetrating head injury: neurology and anatomy. Neurology 1986;36:178187.

34. Grafman J, Salazar AM, Weingartner H, Vance SC, Ludlow CL. Isolated impairment of memory following a penetrating lesion of the fornix cerebri. Arch Neurol 1985;42:1162-1168.

35. Smutok MA, Vance SC, Salazar AM, Foulkes M, Grafman J. Neurologic and anatomic correlates of recovery from hemiparesis following penetrating head injury. Neurology $1985 ; 35: 83$.

36. Ludlow CL, Rosenberg J, Fair C, Buck D, Schlesselman S, Salazar AM. Brain lesions associated with nonfluent aphasia fifteen years following penetrating head injury. Brain $1986 ; 109: 55-80$.

37. Grafman J, Jonas BS, Martin A, et al. Intellectual function following penetrating head injury in Vietnam veterans. Brain 1988;111:169-184.

38. Kraft J, Schwab KA, Salazar AM, Brown HR. Occupational and educational achievements of head injured Vietnam Veterans at 15-year follow-up. Arch Phys Med Rehabil (in press).

39. US Department of Labor, Bureau of Labor Statistics. Labor Force Statistics Derived From the Current Population: A Databook. September 1982;1:Bulletin 2096.

40. Cohany SR. Employment and unemployment among Vietnam-era veterans. Monthly Labor Review, April 1990:2229.

41. Cicerone KD, Wood JC. Planning disorder after closed head injury: a case study. Arch Phys Med Rehabil 1987;68:111115.

42. Elsass L, Kinsella G. Social interaction following severe closed head injury. Psychol Med 1987;17:67-78.

43. Dikmen S, McLean A, Temkin N. Neuropsychological and psychosocial consequences of minor head injury. J Neurol Neurosurg Psychiatry 1986;49:1227-1232.

44. Freedman PE, Bleiberg J, Freedland K. Anticipatory behaviour deficits in closed head injury. J Neurol Neurosurg Psychiatry 1987;50:398-401.

45. Jackson HF, Moffat NJ. Impaired emotional recognition following severe head injury. Cortex 1987;23:293-300.

46. Vogenthaler DR. An overview of head injury: Its consequences and rehabilitation. Brain Inj 1987;1:113-127.

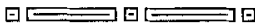 \\ A controlled trial with vasopressin analogue (DGAVP) on cognitive recovery immediately after head trauma
}

\author{
Nicolaas I. Bohnen, MD, PhD; Albert Twijnstra, MD, PhD; and Jellemer Jolles, PhD
}

\begin{abstract}
Article abstract-Recent evidence suggests that the vasopressin analogue desglycinamide-arginine ${ }^{8}$-vasopressin (DGAVP) might specifically benefit mild brain trauma patients. We investigated the effect of intranasal DGAVP treatment in 32 patients who had sustained a mild head injury for 3 months in a double-blind, placebo-controlled, matchedpairs study. DGAVP did not have a positive effect on cognitive recovery in this group of mildly affected patients.
\end{abstract}

NEUROLOGY 1993;43:103-106

Peptides related to the pituitary hormone vasopressin (VP) influence aspects of memory processes and learning in laboratory animals..$^{1,2}$ There have been several clinical studies with vasopressin and related peptides, but the studies differ with respect to the nature of the patients included, methodologic characteristics, pharmacokinetic aspects (dose and route of administration), and the type of VP analogue used. ${ }^{3}$ Some studies reported beneficial effects of peptide administration, whereas others were negative. ${ }^{3}$
The majority of positive findings were obtained either in an open, uncontrolled clinical trial with patients ${ }^{4}$ or in placebo-controlled studies with volunteers. ${ }^{5,6}$ A possible explanation for the discrepant findings is that the peptide might have a specific action on particular cognitive processes and not on others. Most studies where the peptide was ineffective involved patients with a complex pattern of neuropsychologic deficits or other symptoms suggestive of profound brain damage. The lack of effect in patients with structural brain damage is not sur-

From the Department of Neuropsychology and Psychobiology (Drs. Bohnen and Jolles), University of Limburg, Maastricht, and the Department of Neurology (Dr. Twijnstra), University Hospital Maastricht, The Netherlands.

Received March 6, 1992. Accepted for publication in final form June 8, 1992.

Address correspondence and reprint requests to Dr. Nicolaas I. Bohnen, Department of Neuropsychology and Psychobiology, University of Limburg, P.O. Box 616, 6200 MD Maastricht, The Netherlands. 
prising because lesions of the relevant brain structures may have destroyed the sites of action of the peptide.

There have been positive effects in mild, ${ }^{4,7}$ as opposed to severe, brain trauma. ${ }^{8,9}$ The efficacy may depend on the extent of structural lesions. Timsit-Berthier et $\mathrm{al}^{7}$ suggested that the peptide effects developed with time, which may indicate that the treatment period should be longer than a few weeks. We therefore hypothesized that the subjects of choice for VP treatment would be those with early and mild cognitive dysfunction, and the duration of the medication should be sufficiently long. ${ }^{3}$ This is supported by investigations using desglycinamide-arginine ${ }^{8}$-vasopressin (DGAVP) in memory-disturbed patients, ${ }^{10}$ where peptide effects occurred in mild brain trauma but not in patients with a severe trauma.

Mild head injury (MHI) can cause cognitive dysfunction ${ }^{11-13}$ which is maximal in the first weeks after injury and gradually tends to resolve. ${ }^{14} \mathrm{We}$ studied whether an earlier instituted and longer treatment with intranasal VP has an effect on cognitive and subjective recovery in a selected population of patients who had sustained an MHI.

Methods. Subjects. Consecutively hospitalized patients who had sustained an MHI were asked to participate in the study on the basis of informed consent. The criteria for inclusion in the study were a post-traumatic amnesia not exceeding 60 minutes, a period of unconsciousness of less than 15 minutes, a Glasgow Coma Score of 13 to 15 on admission, age between 15 and 70 years, and no serious traumatic physical complication. Patients who had drunk alcohol at the time of the trauma or who had a skull fracture or nose trauma were also excluded. None of the patients had a history of neuropsychiatric disorder.

Patients were assigned pairwise to a treatment regimen with either DGAVP or a placebo (carrier). Both patients and staff were blinded to the medication. Patients were matched in pairs for age ( \pm 6 years), sex, and education $\left( \pm 1\right.$ level $\left.^{15}\right)$. The study was approved by the medical ethical council of the hospital. Fourteen eligible patients did not want to participate, and seven patients were excluded because of noncompliance. Thirty-two patients completed the study. Each group consisted of 16 subjects (nine males and seven females). The mean age in the DGAVP group was 26.1 years $( \pm 14.7)$ and educational level was 5.1 on a 7 -point scale $( \pm 1.0)$. The corresponding means for the placebo group were 27.8 years $( \pm 12.4)$ and $4.5( \pm 0.9)$.

Postconcussive symptoms. A checklist of postconcussive symptoms was completed, which included headache, nausea, dizziness, difficulties with concentration and memory, fatigue, and sleep disturbances. As these symptoms also occur in healthy individuals, ${ }^{16}$ the symptoms were scored for the absolute or increased appearance after the injury in comparison with the pretraumatic condition. Patients were considered asymptomatic if they did not complain of any postconcussive symptoms.

Psychometric tests. The following tests were used: (1) Memory task. A visual, computer-assisted version of the Auditory Verbal Learning Test ${ }^{17}$ (AVLT) was presented on a portable microcomputer. ${ }^{18}$ The AVLT was adapted for the Dutch language. ${ }^{18,19}$ The test consists of a list of
15 monosyllabic meaningful words, which are presented for 1 second at 1-second intervals. At the end of the trial the subjects recall the words. Five trials were carried out. The variable used in this study was the total number of correct words over all trials. Different parallel versions of the AVLT were used in each session.

(2) The Concept Shifting Test ${ }^{20}$ (CST) is a test of visual scanning and conceptual tracking, much like the Trail Making Test. ${ }^{17}$ The CST consists of three subtasks. In each subtask the subject has to cross out small circles containing digits or letters in the correct order. The small circles are arranged in a larger circle on a sheet of paper. The subject was requested to perform the task as quickly as possible. In the first subtask (A) the subject has to cross out consecutively numbered ( 1 to 16) circles, in the second subtask (B) 16 lettered circles (A to P). In subtask $\mathrm{C}$, the subject is presented with 16 circles containing eight digits and eight letters ( $\mathrm{A}$ to $\mathrm{H}$ ) and is asked to alternate between the two sequences (1-A-2-B, etc.). The amount of extra time needed for subtask $\mathrm{C}$ represents the concept-shifting score $[\mathrm{tC}-0.5(\mathrm{tA}+\mathrm{tB}) ; \mathrm{t}=$ time in seconds].

(3) The Stroop Color Word Interference Test ${ }^{17}$ consists of three subtasks. The test examines the speed at which 100 color names (yellow, green, red, and blue) are read (subtask I) and the speed at which 100 colored spots are named (subtask II). Subtask III again involves 100 color names, but the printing ink is different from the color name; the speed at which the color of the printing ink of the words is named is taken as the test variable. The color word interference score was obtained by subtracting the time needed for subtask II from that of subtask III (III - II), and was used as the cognitive parameter.

Design and procedure. Treatments were administered by intranasal spray, each single dose (two puffs) containing either $1 \mathrm{mg}$ DGAVP or placebo (kindly donated by Organon B.V., Oss, The Netherlands). The subjects were instructed to administer themselves four puffs per day (two puffs at breakfast time and two puffs at lunch time); the daily dose was $2 \mathrm{mg}$ DGAVP. The duration of the treatment was 3 months.

Evaluation of the cognitive performance was done by a neuropsychologic assessment at six time points within the 3-month period. As cognitive recovery after MHI is maximal in the first weeks, ${ }^{14}$ the interval between test sessions was shortest immediately after the trauma. This interval increased in the later phases after the trauma, since we expected to find the greatest changes in performance at the beginning of the recovery process. There was one pretreatment assessment at day - 1 . Treatment started 2 days after MHI (day 0). Six post-treatment assessments were at days $3,7,14,28,56$, and 84 .

Drug safety procedure. Liver and renal functions, electrolytes, and total blood count were monitored before entry into the study and at 3 days, 2 weeks, and 8 weeks after the start of treatment.

Statistical analysis. Test scores were analyzed with repeated-measures analysis of variance. ${ }^{21}$ The only grouping factor was the treatment variable (DGAVP versus placebo). As recovery after MHI is maximal in the first weeks after the injury, tests were performed at 1 and 3 months after the trauma. Because of the risk of increasing the statistical error due to performing multiple $\mathrm{F}$ tests, the Bonferroni correction ${ }^{22}$ was applied to adjust the significance levels. Therefore, a probability level of less than 0.005 was considered significant.

Results. The results of the cognitive tasks are pre- 
Table. Results of neuropsychologic test (means \pm SD)

\begin{tabular}{|c|c|c|c|c|c|c|c|c|}
\hline \multirow[b]{2}{*}{ No. } & \multirow[b]{2}{*}{ Session } & \multicolumn{3}{|c|}{ AVLT-tot } & \multicolumn{2}{|c|}{ Concept shifting } & \multicolumn{2}{|c|}{ Stroop interference } \\
\hline & & DGAVP & & Placebo & DGAVP & Placebo & DGAVP & Placebo \\
\hline 1 & Day 3 & $43.9 \pm 5.4$ & & $42.8 \pm 7.6$ & $10.6 \pm 5.5$ & $8.9 \pm 6.4$ & $34.6 \pm 12.1$ & $31.2 \pm 11.9$ \\
\hline 2 & Day 7 & $40.8 \pm 8.4$ & & $43.7 \pm 7.4$ & $8.3 \pm 4.5$ & $10.0 \pm 8.2$ & $31.4 \pm 15.5$ & $21.8 \pm 5.6$ \\
\hline 3 & Day 14 & $48.0 \pm 9.4$ & & $48.4 \pm 8.4$ & $10.6 \pm 5.8$ & $8.6 \pm 7.1$ & $27.0 \pm 10.9$ & $22.0 \pm 5.9$ \\
\hline 4 & Day 28 & $47.3 \pm 9.2^{1}$ & & $48.8 \pm 8.1^{2}$ & $7.2 \pm 7.9^{5}$ & $7.1 \pm 4.3^{6}$ & $25.6 \pm 8.5^{9}$ & $19.7 \pm 8.3^{10}$ \\
\hline 5 & Day 56 & $51.9 \pm 9.2$ & & $54.0 \pm 7.8$ & $4.9 \pm 4.5$ & $7.4 \pm 6.5$ & $22.4 \pm 11.5$ & $19.2 \pm 4.3$ \\
\hline 6 & Day 84 & $50.6 \pm 12.3^{3}$ & & $52,0 \pm 9.6^{4}$ & $9.3 \pm 6.5^{7}$ & $6.1 \pm 5.1^{8}$ & $24.2 \pm 8.7^{11}$ & $19.8 \pm 4.9^{12}$ \\
\hline \multicolumn{9}{|c|}{$\begin{array}{l}\text { F-values (repeated measures ANOVA) of the overall time effect and time } \times \text { DGAVP interaction terms are presented (Bonferroni corrected } \\
\text { significance levels). AVLT-tot }=\text { total number of correctly recalled words; Stroop interference }=\text { Stroop color word interference score. }\end{array}$} \\
\hline \multicolumn{3}{|c|}{$\begin{aligned} 1 & \text { Time: } \mathrm{F}(3,28)=11.66, p<0.001 \\
3 & \text { Time: } \mathrm{F}(5,25)=13.02, p<0.001 \\
5 & \text { Time: } \mathrm{F}(3,24)=1, \mathrm{NS} \\
7 & \text { Time: } \mathrm{F}(5,23)=1.27, \mathrm{NS} \\
9 & \text { Time: } \mathrm{F}(3,27)=13.54, p<0.001 \\
11 & \text { Time: } \mathrm{F}(3,26)=10.11, p<0.001\end{aligned}$} & \multicolumn{3}{|c|}{$\begin{aligned} 2 & \text { Time } \times \text { DGAVP: } \mathrm{F}(3,28)<1, \mathrm{NS} . \\
4 & \text { Time } \times \text { DGAVP: } \mathrm{F}(5,25)<1, \mathrm{NS} . \\
6 & \text { Time } \times \text { DGAVP: } \mathrm{F}(3,24)<1, \mathrm{NS} . \\
8 & \text { Time } \times \text { DGAVP: } \mathrm{F}(5,23)<1, \mathrm{NS} . \\
10 & \text { Time } \times \text { DGAVP: } \mathrm{F}(3,27)=1.11, \mathrm{NS} . \\
12 & \text { Time } \times \text { DGAVP: } \mathrm{F}(3,26)=2.24, \mathrm{NS} .\end{aligned}$} & & & \\
\hline
\end{tabular}

sented in the table. Repeated-measures analysis of variance demonstrated a significant time effect for the scores of the verbal memory test after 1 month $[\mathrm{F}(3,28)=11.66, p<0.001]$ and 3 months $[\mathrm{F}(5,25)=$ $13.02, p<0.001]$. Similar findings were done for the Stroop interference measure for 1 month $[\mathrm{F}(3,27)=13.54, p<0.001]$ and for 3 months $[F(3,26)=10.11, p<0.001]$, indicating that there was a significant improvement after the injury. There was no significant time effect for the concept-shifting score for 1 month $[\mathrm{F}(3,24)=1$, NS $]$ and for 3 months $[F(5,23)=1.27, \mathrm{NS}]$ after the injury (table).

With respect to the DGAVP treatment, there was no significant time $\times$ DGAVP interaction for any of the cognitive parameters at 1 or 3 months after the trauma (table). This indicates that the groups did not differ in the mean rate of cognitive recovery from MHI.

There was no significant difference between the two groups in the number of asymptomatic patients at 1 month (chi-square $=0.67 ; \mathrm{NS}$ ) and 3 months (chi-square $=0.01 ; \mathrm{NS}$ ).

Discussion. The present results do not support the hypothesis that DGAVP affects the early cognitive recovery from an MHI. Recent evidence suggests that around $25 \%$ of patients with MHI may have persistent cognitive and neurobehavioral sequelae at 6 months postinjury. ${ }^{23,24}$ This and the positive findings in the Hijman et al study ${ }^{10}$ of patients with persistent postconcussional symptoms suggest that a possible DGAVP effect may be confined to a subgroup of trauma patients with different profiles of cognitive dysfunctions.

Future studies with DGAVP should focus on selected groups of mildly head-injured patients suffering from the persistent postconcussional syndrome to test the hypothesis from earlier research that positive findings with DGAVP are confined to this patient population. ${ }^{10}$

\section{Acknowledgments}

The authors acknowledge the personnel and staff of the Department of Neurology, University Hospital Maastricht, for their contribution in the study.

\section{References}

1. De Wied D. The influence of posterior and intermediate lobe of the pituitary and pituitary peptides on the maintenance of a conditioned avoidance response in rats. Int J Neuropharmacol 1965;4:157-167.

2. Van Wimersma Greidanus TjB, Jolles J, De Wied D. Hypothalamic neuropeptides and memory. Acta Neurochir (Wien) 1985;75:99-105.

3. Jolles J. Vasopressin and human behavior. In: Gash DM, Boer GJ, eds. Vasopressin: principles and properties. New York: Plenum Press, 1987:549-578.

4. Oliveros JC, Jandali MK, Timsit-Berthier M, et al. Vasopressin in amnesia. Lancet 1978;1:42.

5. Beckwith BE, Till RE, Schneider V. Vasopressin analog (DDAVP) improves memory in human males. Peptides 1984;5:819-822.

6. Nebes RD, Reynolds CF, Horn LC. The effect of vasopressin on memory in the healthy elderly. Psychiatry Res 1984;11:49-59.

7. Timsit-Berthier M, Mantanus H, Jacques MC, Legros JJ. Utilité de la lysine-vasopressine dans le traitement de l'amnésie post-traumatique. Acta Psychiatr Belg 1980;80:728-747.

8. Fewtrell WD, House AO, Jamie PF, Oates MR, Cooper JE. Effects of vasopressin on memory and new learning in a brain-injured population. Psychol Med 1982;12:423-425.

9. Reichert WH, Blass JP. A placebo-controlled trial shows no effect of vasopressin on recovery from closed head injury. Ann Neurol 1982;12:390-392.

10. Hijman R, Jolles J, Verhoeven WMA, van Ree JM, Elderson A, De Wied D. Desglycinamide-(arg8)-vasopressin in five trials with memory disturbed patients. Human Psychopharmacol 1992;7:7-23.

11. Hugenholtz H, Stuss DT, Stethem LL, Richard MT. How long does it take to recover from a mild concussion? Neurosurgery 1988;22:853-858.

12. Bohnen N, Jolles J. Neurobehavioral aspects of postconcussive symptoms after mild head injury. $J$ Nerv Ment Dis 1992;180:683-692.

13. Bohnen N, 'Twijnstra A, Jolles J. Performance in the Stroop Color Word Test in relationship to persistence of symptoms following mild head injury. Acta Neurol Scand 1992b;85:116-121.

14.Levin HS, Mattis S, Ruff RM, et al. Neurobehavioral out- 
come following minor head injury: a three-center study. J Neurosurg 1987;66:234-243.

15. Verhage R. Intelligentie en leeftijd. Assen, The Netherlands: 1964. Dissertation.

16. Dikmen S, McLean A, Temkin N. Neuropsychological and psychosocial consequences of minor head injury. J Neurol Neurosurg Psychiatry 1986;49:1227-1232.

17. Lezak MD. Neuropsychological assessment, 2nd ed. New York: Oxford University Press, 1983.

18. Brand N, Jolles J. Learning and retrieval of words presented auditorily and visually. J Gen Psychol 1985;112:201-210.

19. Deelman BG, Brouwer WH, van Zomeren AH, Saan RJ. Functiestoornissen na trauma capitis. In: JennekensSchinkel A, ed. Neuropsychologie in Nederland. Deventer, The Netherlands: Van Loghum Slaterus, 1980.

20. Houx PJ, Vreeling FW, Jolles J. Concept shifting ability:
Revised Trail Making Test and Concept Shifting Test. In: Houx PJ, ed. Cognitive aging and health related factors. Maastricht, The Netherlands: University of Limburg, 1991:93-103. Thesis.

21. SAS user's guide: statistics version 5 edition. Cary, NC: SAS Institute, 1985

22. Kleinbaum DG, Kupper LL, Muller KE. Applied regression analysis and other multivariable methods. Boston: PWSKent Publishing, 1988.

23. Bohnen N, Twijnstra A, Wijnen G, Jolles J. Tolerance to light and sound of patients with persistent postconcussional symptoms six months after mild head injury. J Neurol $1991 ; 238: 443-446$.

24. Bohnen N, Jolles J, Twijnstra A. Neuropsychological deficits in patients with persistent symptoms six months after mild head injury. Neurosurgery 1992c;30:692-696.

\title{
Clock-drawing test and unilateral spatial neglect
}

\author{
S. Ishiai, MD; M. Sugishita, DMS, DHS; T. Ichikawa, MD; S. Gono, MD; and S. Watabiki, MD
}

\begin{abstract}
Article abstract-We investigated the ability of 25 patients with left unilateral spatial neglect to make a clock face by putting numbers inside a printed circle. Impairment seen in this clock-drawing test did not parallel neglect severity as judged by results of the line-cancellation and line-bisection tests, as well as the copying of a daisy. The score for clock drawing correlated highly with the verbal WAIS score. Most neglect patients with a verbal IQ of 87 or more could draw a clock face fairly well and used planning in placing the numbers $12,3,6$, and 9 before the others. In clock drawing, verbal intelligence may compensate for left unilateral spatial neglect. We therefore recommend use of the line-cancellation and line-bisection tests, as well as the copying test, but do not recommend use of the clock-drawing test in the diagnosis of left unilateral spatial neglect.
\end{abstract}

NEUROLOGY 1993;43:106-110

The clock-drawing test has been used as a traditional diagnostic measure of unilateral spatial neglect. ${ }^{1-6}$ Patients with left unilateral spatial neglect may place all 12 numbers on the right half of a clock face or place correctly only the hours from 12 to 6 on the right side. ${ }^{3,5,6}$ Some patients who demonstrate typical left unilateral spatial neglect in other tests, however, show no or only slight impairment in clock drawing. ${ }^{7}$ Patients with dementia may have difficulty in drawing a clock face. ${ }^{8-10}$ Intelligence, therefore, may also influence the performances of neglect patients in the clockdrawing test. We investigated the role of intellectual decline in the ability to make clock drawings and reappraised the efficacy of the clock-drawing test as a diagnostic measure of left unilateral spatial neglect by comparing it with other tests of neglect.
Methods. Subjects. Twenty-five patients with left unilateral spatial neglect took part in the study. All were fully right-handed in the activities included in the questions for handedness in the Western Aphasia Battery, Japanese edition. ${ }^{11}$ Ages ranged from 47 to 79 years (mean, 61.4 years), and the duration after onset of the condition was from 1 to 22 months (mean, 7.4 months). The diagnosis of lesions was made from results of CT examinations. Twenty-three subjects had right middle cerebral artery territory infarcts that involved the parietal and temporal lobes and, to some extent, the frontal lobe. Two had deep lesions - an anterior choroidal artery territory infarction and a thalamic hemorrhage. All subjects had apparent left hemiparesis and used the right hand in each test. Judgment of verbal and performance intelligence was based on the Wechsler Adult Intelligence Scale (WAIS), Japanese edition. ${ }^{12}$ Informed consent for testing was obtained from all subjects.

Clock-drawing test. We asked the subjects to place

From the Department of Rehabilitation (Drs. Ishiai and Sugishita), Tokyo Metropolitan Institute for Neuroscience, Tokyo; the Department of Neurology (Dr. Ichikawa), Saitama Rehabilitation Center, Saitama; the Department of Neurology (Dr. Gono), Rehabilitation Center Kakeyu Hospital, Nagano; and the Department of Neurology (Dr. Watabiki), Musashino Red Cross Hospital, Tokyo, Japan.

Received November 25, 1991. Accepted for publication in final form June 4, 1992.

Address correspondence and reprint requests to Dr. Sumio Ishiai, Department of Rehabilitation, Tokyo Metropolitan Institute for Neuroscience, 2-6 Musashidai, Fuchu City, Tokyo 183, Japan. 